\title{
Effects of Brazilian green propolis glycolic solutions against bacterial biofilm on elastomers used in maxillofacial prostheses
}

\author{
Efeitos das soluções glicólicas da própolis verde brasileira frente ao biofillme bacteriano em \\ elastômeros usados em próteses maxilofaciais \\ Efecto de soluciones glicólicas de propóleo verde Brasileño frente a la biopelícula bacteriana en \\ elastómeros utilizados en prótesis maxilofaciales
}

Received: 02/08/2022 | Reviewed: 02/15/2022 | Accept: 02/19/2022 | Published: 03/01/2022

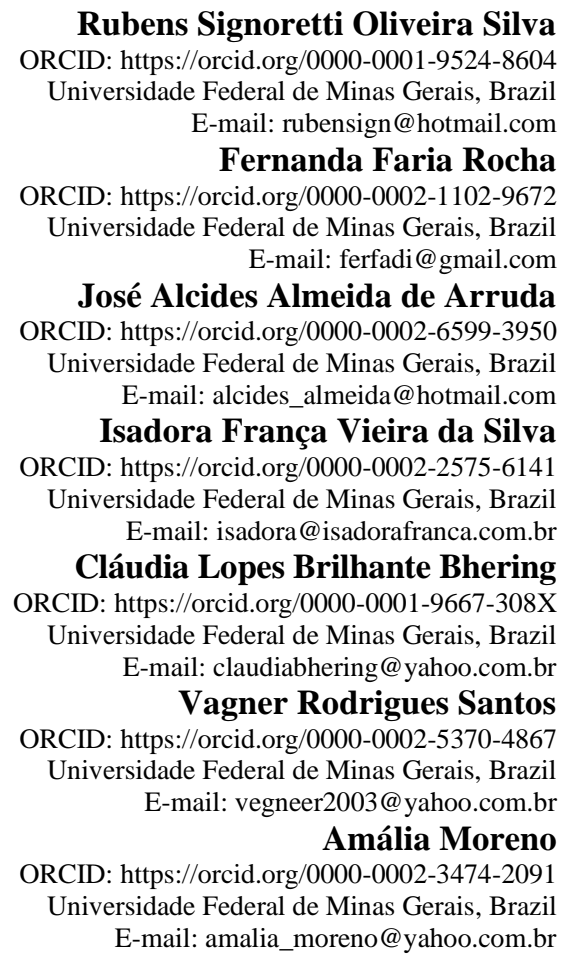

\begin{abstract}
Maxillofacial prostheses are among the modalities of prosthetic rehabilitation but the disinfectant solutions for their cleaning have been barely explored. The purpose of the present study was to evaluate the antibacterial effects of a Brazilian green propolis glycolic (PGL) solution on the removal of biofilm from the surface of two maxillofacial elastomers (room temperature vulcanization [RTV] and high consistency silicone rubber [HCR]). A total of 42 specimens $(3 \times 10 \mathrm{~mm})$ were made with these two elastomers and Staphylococcus aureus was allowed to grow for 24 hours on the surface of the biomaterials. Specimens $(n=3)$ were randomly allocated to the following treatment groups by immersion for 15 minutes: $0.9 \%$ saline solution; 2\% chlorhexidine gluconate (CHX); 11\%, 16\% and 20\% PGL; and Daro Brand® antimicrobial liquid agent and antibacterial gel soap. Quantitative assessment was performed by counting the number of colony-forming units (CFU). Two-way ANOVA was employed for data analysis. Specimens of both maxillofacial elastomers treated with PGL solutions at concentrations of $11 \%, 16 \%$ and $20 \%$, as well as $2 \%$ $\mathrm{CHX}$, did not reveal $\mathrm{CFU} / \mathrm{mL}$ of the $S$. aureus strain, indicating the broad spectrum of antibiofilm action of these disinfectant solutions. In addition, the Daro Brand® antimicrobial liquid agent showed lower CFU/mL in both maxillofacial elastomers compared to the Daro Brand® gel soap and $0.9 \%$ saline solution. Therefore, disinfection with PGL solutions is effective and might be considered to be a promising alternative in eliminating the $S$. aureus biofilm from specimens of maxillofacial elastomers by immersion for 15 minutes.
\end{abstract}

Keywords: Biofilm; Dental materials; Maxillofacial prosthesis; Propolis; Staphylococcus aureus. 


\begin{abstract}
Resumo
As próteses maxilofaciais estão entre as modalidades de reabilitação protética, mas as soluções desinfetantes para sua limpeza são pouco exploradas. O objetivo do presente estudo foi avaliar os efeitos antibacterianos de uma solução brasileira de própolis verde glicólica (PVG) na remoção de biofilme da superfície de dois elastômeros maxilofaciais (vulcanização a temperatura ambiente [VTA] e borracha de silicone de alta consistência [BSAC]). Um total de 42 espécimes $(3 \times 10 \mathrm{~mm})$ foram confeccionados com esses dois elastômeros e Staphylococcus aureus foi deixado em contato por 24 horas na superfície dos biomateriais. As amostras $(n=3)$ foram alocadas aleatoriamente nos seguintes grupos de tratamento por imersão por 15 minutos: solução salina a $0,9 \%$; gluconato de clorexidina a $2 \%$ (CHX); $11 \%$, $16 \%$ e $20 \%$ de PVG; e agente líquido antimicrobiano Daro Brand® e sabonete em gel antibacteriano. A avaliação quantitativa foi realizada pela contagem do número de unidades formadoras de colônia (UFC). ANOVA de duas vias foi empregada para análise de dados. Espécimes de ambos os elastômeros maxilofaciais tratados com soluções de PVG nas concentrações de $11 \%, 16 \%$ e $20 \%$, bem como $2 \% \mathrm{CHX}$, não revelaram UFC/mL da cepa $S$. aureus, indicando o amplo espectro de ação antibiofilme dessas soluções desinfetantes. Além disso, o agente líquido antimicrobiano Daro Brand® apresentou menor UFC/mL em ambos os elastômeros maxilofaciais em comparação ao sabonete em gel Daro Brand® e solução salina 0,9\%. Portanto, a desinfecção com soluções de PVG é eficaz e pode ser considerada uma alternativa promissora na eliminação do biofilme de $S$. aureus de espécimes de elastômeros maxilofaciais por imersão por 15 minutos.
\end{abstract}

Palavras-chave: Biofilme; Materiais dentários; Prótese maxilofacial; Própolis; Staphylococcus aureus.

\title{
Resumen
}

Las prótesis maxilofaciales se encuentran entre las modalidades de rehabilitación protésica, pero las soluciones desinfectantes para su limpieza son poco investigadas. El objetivo del presente estudio fue evaluar el efecto antibacteriano de una solución Brasileña de propóleo verde glicólico (PVG) para remoción de biopelícula de la superficie de dos elastómeros maxilofaciales (vulcanización a temperatura ambiente [VTA] y caucho de silicona de alta consistencia [CSAC]). Se realizaron un total de 42 muestras $(3 \times 10 \mathrm{~mm})$ con estos dos elastómeros y dejados en contacto con Staphylococcus aureus durante 24 horas sobre su superficie. Las muestras $(\mathrm{n}=3)$ fueron colocadas aleatoriamente en los siguientes grupos de tratamiento de inmersión durante 15 minutos: solución salina al 0,9\%; gluconato de clorhexidina al 2\% (CHX); 11\%, 16\% y 20\% PVG; y agente líquido antimicrobiano y jabón en gel antibacterial Daro Brand®. La evaluación cuantitativa se realizó contando el número de unidades formadoras de colonias (UFC). Para el análisis de datos se utilizó ANOVA de dos vías. Las muestras de ambos elastómeros maxilofaciales tratados con soluciones de PVG a concentraciones de $11 \%, 16 \%$ y $20 \%$, así como con CHX al $2 \%$, no revelaron UFC/mL de la cepa de $S$. aureus, lo que indica el amplio espectro de actividad antibiopelícula de estas soluciones. Además, el agente antimicrobiano líquido Daro Brand® mostró menores UFC/mL en ambos elastómeros maxilofaciales en comparación con el jabón en gel Daro Brand® y la solución salina al 0,9 \%. Por lo tanto, la desinfección con soluciones de PVG es eficaz y puede considerarse una alternativa prometedora en la eliminación del biopelícula de $S$. aureus en las muestras de elastómeros en inmersión durante 15 minutos.

Palabras clave: Biopelícula; Materiales dentales; Prótesis maxilofacial; Própolis; Staphylococcus aureus.

\section{Introduction}

Over the past 40 years, maxillofacial prosthesis research has concentrated on patient-reported outcome measures. This comprises the lifelong maintenance and replacement of maxillofacial prostheses (Jablonski et al, 2021). The manufacturing of these artificial or alloplastic prostheses with biomaterials permits the reconstruction of lost substance in the head and neck region, thus providing patient rehabilitation and restoring anatomy, function, and esthetics, in addition to social reintegration and improved quality of life (Caxias et al, 2019; Goiato et al, 2009). Maxillofacial elastomers are the materials closest to ideal for maxillofacial prostheses because of easy handling, good physical and mechanical properties, biocompatibility, relatively low cost, and satisfactory characterization and pigmentation (Hatamleh et al, 2016; Mulcare; Coward, 2019; Rahman et al, 2019; Sonnahalli \& Chowdhary, 2020). Since these materials are in contact with bodily fluids (e.g., blood, sweat, and tears), their use may involve some problems such as water absorption, permanent deformation, superficial deterioration, and long-term color change (Santos et al, 2012; Filié Haddad et al, 2011; Guiotti et al, 2016; Miranda et al, 2019).

The surface of the maxillofacial prosthesis can be a reservoir of microorganisms mainly associated with cases of dermatitis and endophthalmitis (Ariani et al, 2012). Among the microorganisms that colonize the maxillofacial prosthesis and the skin underneath the prosthesis are coagulase-positive staphylococci, whose main representative is Staphylococcus aureus 
(Guiotti et al, 2018; Pinheiro et al, 2018). They live mainly on mucous surfaces and are considered to be some of the most versatile and harmful human pathogens (Guiotti et al, 2018; Tong et al, 2015). Previous studies have linked the presence of microorganisms on maxillofacial prostheses to local and systemic infections (Ariani et al, 2012; Goiato et al, 2010; Guiotti $e t$ $a l, 2016$; Li et al, 2000; Miranda et al, 2019). In this respect, proper care and cleaning should be considered as a form of prevention. For the establishment of effective disinfection protocols, knowledge of the biofilm formed on maxillofacial prostheses and their closely related tissues is essential (Goiato et al, 2010; Guiotti et al, 2016; Miranda et al, 2019); however, this is still a barely explored topic (de Caxias et al, 2019).

The chemical immersion technique is essentially the method of choice for the cleaning of maxillofacial prostheses by careful rubbing of their internal surface (Filié Haddad et al, 2011; Guiotti et al, 2016; Paranhos et al, 2007). Although the chlorhexidine gluconate (CHX) solution has been widely employed as an antimicrobial disinfectant (de Azevedo et al, 2021; Filié Haddad et al, 2011; Guiotti et al, 2016; Miranda et al, 2019; Moreno et al, 2020), possible structural damage to biomaterials has been observed with its use, such as roughness and microhardness as the main altered physical and mechanical properties of maxillofacial silicone elastomers (Moreno et al, 2013); however, divergent results have been reported elsewhere (Chamaria et al, 2019). In addition, Daro Brand ${ }^{\circledR}$ is a commercial antibacterial product used as an alternative for cleaning maxillofacial prostheses, but no studies have proved its effects as a disinfectant.

Recent literature has suggested the use of propolis as a biofilm disinfectant in maxillofacial prostheses (de Azevedo et al, 2021; Guiotti et al, 2016; Miranda et al, 2019). Brazilian green propolis has multiple biological and pharmacological properties and its mechanisms of action include anti-inflammatory, antioxidant, and immunomodulatory properties (Sforcin, 2016; Yamaga et al, 2021). Among its chemical compounds of botanical origin are mainly cinnamic acid derivatives and flavonoids (Sforcin, 2016; Yamaga et al, 2021). Our research group has previously demonstrated that different Brazilian green propolis solutions represent a safe and low-cost alternative for cleaning polymers used for maxillofacial prostheses, including ocular prostheses, since no bacteria were found on the surface of the prosthetic materials treated with them (de Azevedo et al, 2021). We also reported that the high consistency rubber (HCR) silicone of elastomers disinfected with $11 \%$ solutions of Brazilian glycolic and aqueous green propolis extracts has proved to be clinically acceptable, causing imperceptible color alterations (Miranda et al, 2019).

In view of these encouraging results, we decided to evaluate herein the effects of disinfection with Brazilian green propolis glycolic (PGL) solutions compared to conventional and well-established cleaning solutions, including CHX agent and Daro Brand ${ }^{\circledR}$ antimicrobial liquid and antibacterial gel soap against $S$. aureus biofilms in maxillofacial silicone elastomers used in maxillofacial prostheses.

\section{Methodology}

\subsection{Specimen manufacturing}

In this in vitro study, two types of maxillofacial silicone elastomers were used: room-temperature vulcanizing (RTV; MDX4-4210, Dow Corning Corp., Midland, MI, USA) and HCR (Q7-4735, Dow Corning Corp.) (Table 1) to manufacture 42 disk-shaped specimens ( $3 \mathrm{~mm}$ in thickness and $10 \mathrm{~mm}$ in diameter), which served as substrates for the development of bacterial biofilm, compared to treatments with the proposed antimicrobial solutions. The specimens were fabricated in a metal matrix using a dental flask (VIPI STG; VIPI Ind. Com. Ltd., Pirassununga, SP, Brazil) according to previously published methods (de Azevedo et al, 2021; Miranda et al, 2019). 
Table 1. Manufacturers and chemical composition of the maxillofacial silicone elastomers and disinfectants used.

\begin{tabular}{|c|c|c|c|}
\hline Source & Material & Manufacturer & Chemical composition \\
\hline \multirow{2}{*}{ Elastomers } & $\begin{array}{c}\text { MDX4-4210, Room } \\
\text { Temperature Vulcanization } \\
\text { (RTV) }\end{array}$ & Dow Corning Corp. & Poly(dimethylsiloxane) \\
\hline & $\begin{array}{l}\text { Q7-4735, High Consistency } \\
\text { Rubber (HCR) }\end{array}$ & Dow Corning Corp. & $\begin{array}{l}\text { One-part uncatalyzed silicone elastomer } \\
\text { raw material }\end{array}$ \\
\hline \multirow{7}{*}{ Disinfectants } & Control - saline water $(0.9 \%)$ & & $0.9 \% \mathrm{NaCl}$ in distilled water \\
\hline & $11 \%$ Propolis glycolic extract & & \\
\hline & $16 \%$ Propolis glycolic extract & Bee Propolis Brasil & Propylene glycol \\
\hline & $20 \%$ Propolis glycolic extract & & \\
\hline & $2 \%$ chlorhexidine solution & Maquira & $\begin{array}{l}2 \% \text { chlorhexidine gluconate, } \\
\text { methylparaben, purified water }\end{array}$ \\
\hline & $0.12 \%$ chlorhexidine solution & Noplak & Chlorhexidine $0.12 \%+$ Cetylpyridinium \\
\hline & $\begin{array}{l}\text { Antibacterial Daro Brand® } \\
\text { soap gel } \\
\text { Antimicrobial Daro Brand® } \\
\text { liquid }\end{array}$ & Factor II Inc. & Not available \\
\hline
\end{tabular}

Source: Authors.

\subsection{Hardness evaluation}

The Shore A hardness of the specimens was determined with a durometer (Mitutoyo Digital HH-336, Hardmatic Durometer, São Paulo, SP, Brazil) to verify the adequacy of the values of this mechanical property of the material after polymerization, according to manufacturer information. For each specimen, three readings were performed on both surfaces, and the final mean of these values was obtained. The specimens whose Shore A hardness values did not fit the manufacturer's standards were discarded. The mean hardness value was 30.90 Shore A for specimens manufactured with RTV and 39.27 Shore A for those manufactured with HCR.

\subsection{Disinfectant solutions}

The solutions proposed for the study were: (1) $0.9 \%$ saline solution; (2) $0.12 \%$ CHX (Noplak Max oral solution with fluoride; Daudt); (3) 2\% CHX (Maquira), (4-6) Brazilian PGL solutions at 11\%, 16\%, and 20\% concentration (Bee Propolis Brasil), (7) DaroBrand $®$ liquid antimicrobial agent (Factor II Inc.); and (8) DaroBrand® antibacterial gel soap (Factor II Inc.) (Table 1).

\subsection{Microbiological assessment}

The ATCC 25923 strain of $S$. aureus was used in the study. To prepare the $S$. aureus inoculum, the bacteria were kept at $-70^{\circ} \mathrm{C}$ in a solution containing $25 \%$ glycerol, seeded in glass tubes containing brain heart infusion (BHI) broth culture medium (HiMedia Laboratories Pvt. Ltd., Mumbai, India), and incubated at $37^{\circ} \mathrm{C}$ (Henriques et al, 2005). The culture was started in $10 \mathrm{~mL}$ of BHI broth and allowed to grow for 24 hours at $35^{\circ} \mathrm{C}$. To determine the intensity of multiplication in liquid 
culture media, the sample was compared to the McFarland nephelometric scale (Probac do Brasil Produtos Bacteriológicos Ltd., São Paulo, SP, Brazil).

For the pilot study, $400 \mu \mathrm{L}$ of the liquid culture medium (BHI broth) plus the $S$. aureus inoculum were seeded in a petri dish containing BHI agar as the culture medium (KASVI, São José dos Pinhais, PR Brazil). The specimens were randomly allocated to the plates, sterile paper discs $8 \mathrm{~mm}$ in diameter, and $20 \mu \mathrm{L}$ of the treatments proposed for the study were placed on the surface of the paper discs.

After dripping, the plates ( $\mathrm{n}=4)$ were incubated and left to stand at $35^{\circ} \mathrm{C}$ for 24 hours. After bacterial growth, when the presence of halos around the disc was observed (positive inhibition halo), this meant that the disinfectant solution was able to inhibit the growth of the strain and, conversely, when there were no inhibition halos (inhibition halo-negative), there was no growth of the strain. In the case of positive halos, their diameters were measured (in mm), and the mean result was calculated.

For quantitative research, the methods previously described in detail were employed (Gonçalves et al, 2020). Started under aseptic conditions, the specimens were transferred individually in a horizontal position to a 24-well culture plate containing $0.9 \mathrm{~mL}$ of BHI broth culture medium (HiMedia Laboratories Pvt. Ltd., Mumbai, India). Next, $100 \mu \mathrm{L}$ of S. aureus inoculum at a concentration of $10^{8}$ cells $/ \mathrm{mL}$, was added to the BHI broth in each well of the plate. The specimens were kept at $35^{\circ} \mathrm{C}$ for 24 hours (initial growth phase of the biofilm) under microaerophilic conditions $\left(5 \% \mathrm{CO}_{2}\right)$. After the 24-hour incubation period, the specimens were treated with the solutions selected for the study and randomly distributed $(\mathrm{n}=3)$. Colonized specimens from the 24-well plate were removed and washed in $1 \mathrm{~mL} 0.9 \%$ saline solution to remove loosely adhered cells, and individually immersed in a new 24 -well culture plate containing $1 \mathrm{~mL}$ of each disinfectant solution for 15 minutes, and then washed again. For the treatment with the antibacterial Daro Brand® soap gel, the specimens were immersed for 20 seconds, simulating a usual wash.

After cleaning, the specimens were separately immersed in Falcon tubes containing $1 \mathrm{~mL} 0.9 \%$ saline solution. For the detachment of the biofilm adhered to the discs, each falcon tube containing the disc was individually vortexed three times ( $7 \mathrm{~W}$ for $60 \mathrm{~s}$, with a 5-minute pause between each shake in an ice bucket). Next, the suspensions containing the biofilm were homogenized and serially diluted with $900 \mu \mathrm{L}$ of saline solution, $0.9 \%$ for each $100 \mu \mathrm{L}$ of sample. For the seeding of the serial dilution, the micro-drop technique was applied to a petri dish containing BHI agar. Thus, each Petri dish corresponded to a treatment group, being divided into five sessions identified by dilution: $10^{-1}$ to $10^{-6}$. For each dilution, 3 drops of $10 \mu \mathrm{L}$ were applied, removed from the diluted suspensions. The petri dishes were incubated at $35^{\circ} \mathrm{C}$ in an anaerobic environment for 24 hours. The number of colony forming units $(\mathrm{CFU} / \mathrm{mL})$ was obtained from the average between the colony count of the 3 drops for each dilution, multiplied by a correction factor and the inverse of the dilution.

\subsection{Data analysis}

The Statistical Package for the Social Sciences (SPSS) software (IBM SPSS Statistics for Windows, version 25.0, Armonk, NY: IBM Corp.) was employed for data analysis. The Box-Cox transformation was used to obtain data according to the normal distribution for the Kolmogorov-Smirnov test. The transformation indicated that the natural logarithmic function (ln) applied to the data met the assumptions of Analysis of Variance (ANOVA). Two-way ANOVA was employed to determine significant differences between the factors analyzed, i.e., type of facial silicone elastomer and disinfection treatments. Significant differences in the values obtained by ANOVA were compared by the Tukey HSD test. For all analyses, the level of significance was set at $<0.05$. 


\section{Results}

The pilot study initially carried out revealed that the PGL solution used as an antibacterial agent against the $S$. aureus strain was effective in inhibiting biofilm growth on paper discs, and discs soaked in PGL solution showed positive inhibition of halos after 24 hours of growth of the microorganisms. In contrast, Daro Brand® liquid was less efficient since it did not induce a halo around the disc. The diameters of the $S$. aureus halos formed around the samples treated with the proposed solutions were as follows: $0.9 \%$ saline solution: $0 \mathrm{~mm}$; $2 \%$ CHX: $10 \mathrm{~mm}$; 0.12\% CHX: $7 \mathrm{~mm}$; PGL at 11\%, 16\% and 20\% concentrations: 18, 19 and $17 \mathrm{~mm}$ (respectively); Daro Brand® liquid: $8 \mathrm{~mm}$; and Daro Brand® soap gel: $0 \mathrm{~mm}$ (Figure 1).

Figure 1. Paper discs with Staphylococcus aureus inhibition halos for the proposed solutions: (1) $0.9 \%$ saline; (2) $2 \%$ chlorhexidine gluconate; (3) $0.12 \%$ chlorhexidine; (4-6) Brazilian green propolis glycolic solutions at 11\%, 16\%, and 20\% concentrations; (7) Daro Brand $®$ antimicrobial liquid; and (8) Daro Brand $®$ antibacterial soap gel.

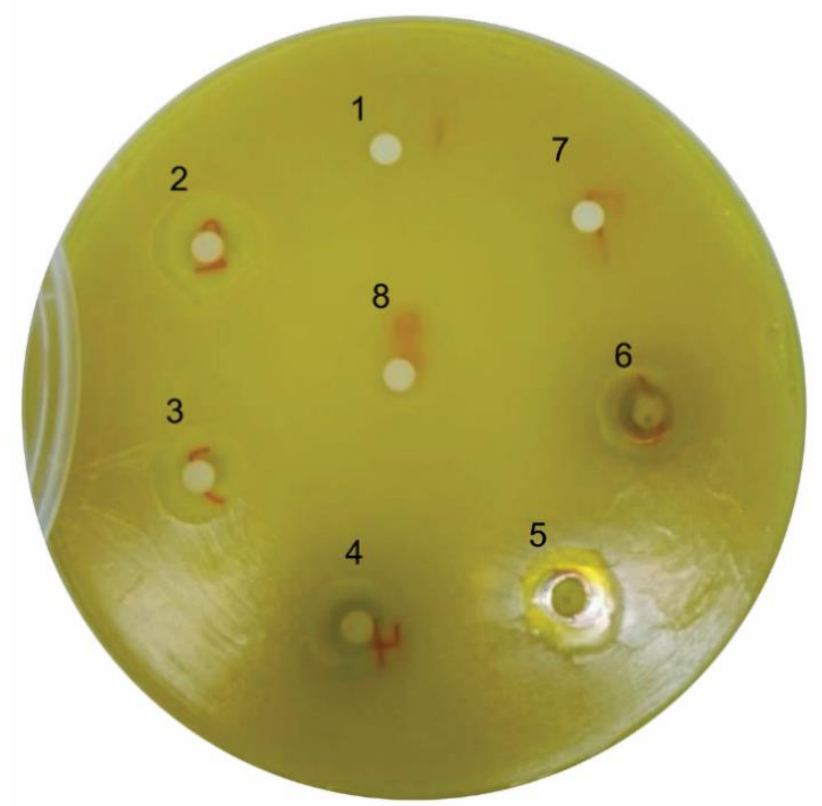

Source: Authors.

In quantitative research, specimens of both maxillofacial elastomers treated with PGL at all concentrations (11\%, $16 \%$ and $20 \%$ ) and with $2 \%$ CHX (negative control) did not show CFU of the S. aureus strain, revealing the broad antibiofilm spectrum of these treatments (Figure 2 and Figure 3). The mean values and standard errors of CFU for each type of maxillofacial elastomer and disinfectant treatment are illustrated in Figure 4. There was no statistically significant difference between the factors of the maxillofacial elastomer type and the interaction between type and treatment ( $p>0.05)$. In contrast, the disinfectant treatment was statistically significant $(p=0.020)$ (Table 2). 
Figure 2. Petri dishes prepared from the residual biofilm of room temperature vulcanization (RTV) discs after incubation at $37^{\circ} \mathrm{C}$ for 24 hours in order to count the colony units formed per milliliter.

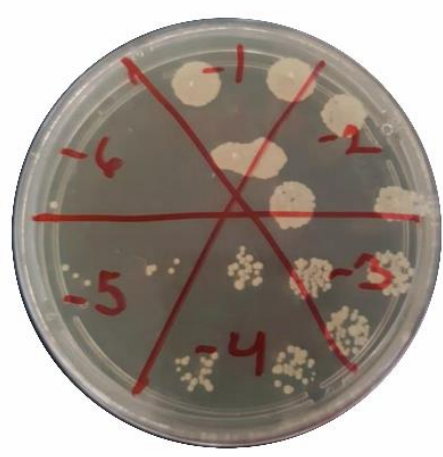

$0.9 \% \mathrm{NaCl}$

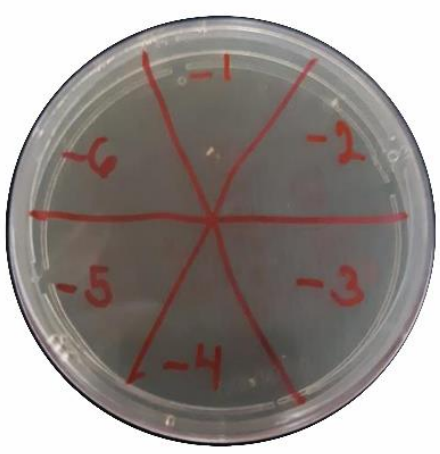

$2 \% \mathrm{CHX}$

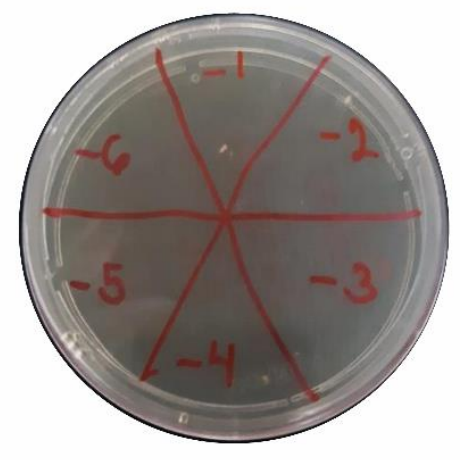

$11 \%$ PGL

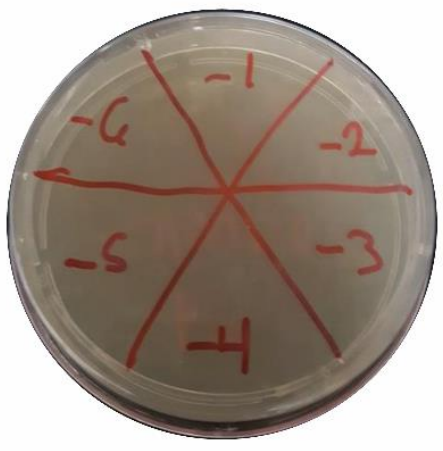

$16 \%$ PGL

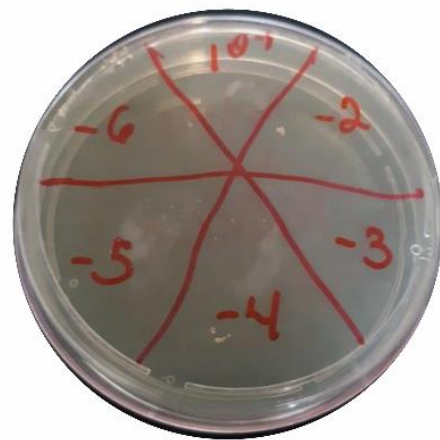

$20 \%$ PGL
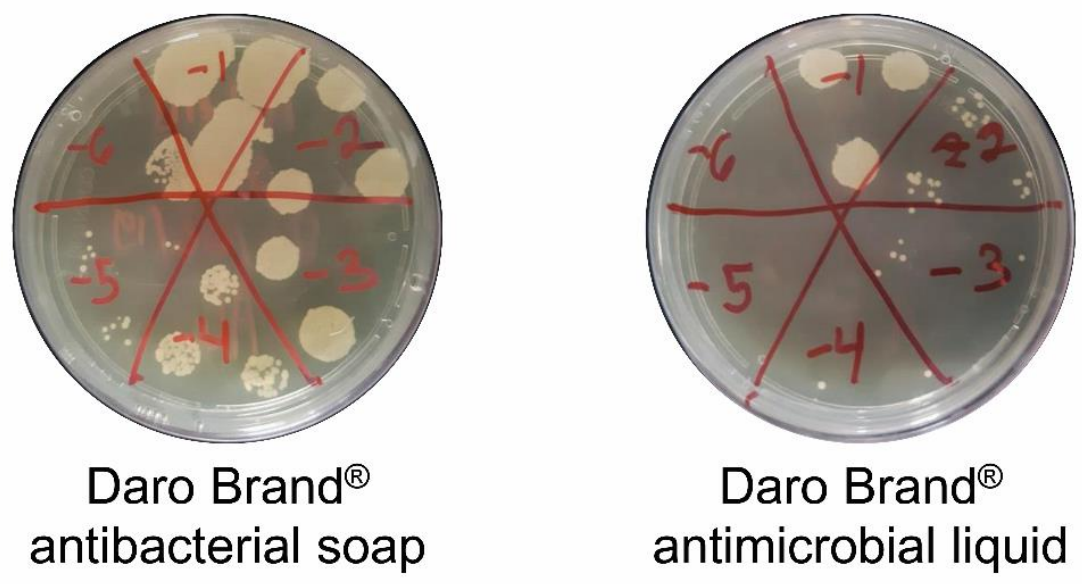
Figure 3. Petri dishes prepared from the residual biofilm of high consistency silicone (HCR) discs after incubation at $37^{\circ} \mathrm{C}$ for 24 hours in order to count the colony units formed per milliliter.
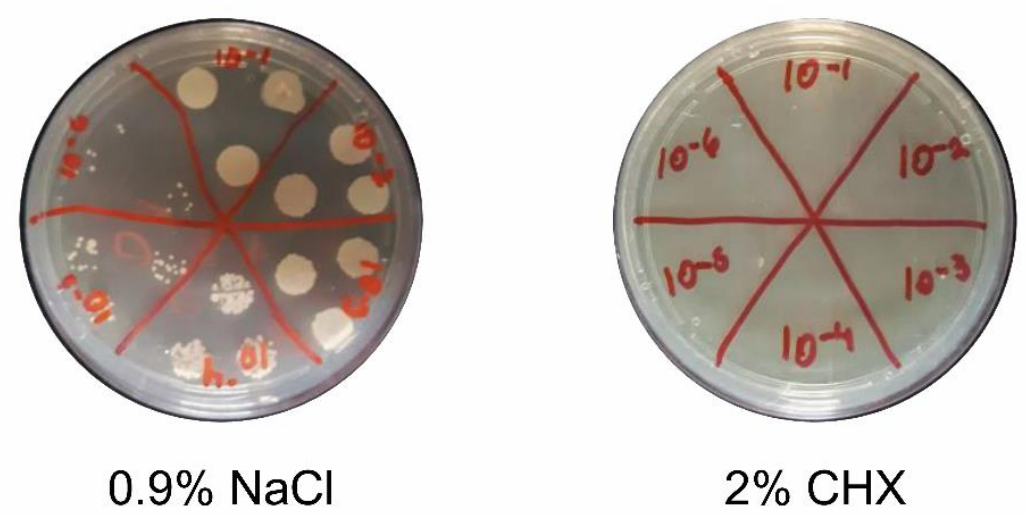

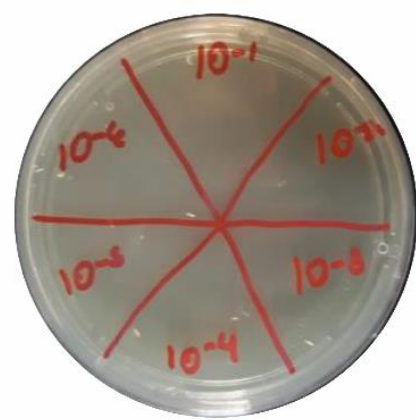

$11 \%$ PGL

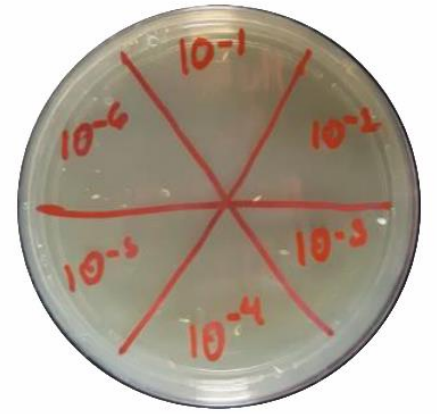

$16 \%$ PGL

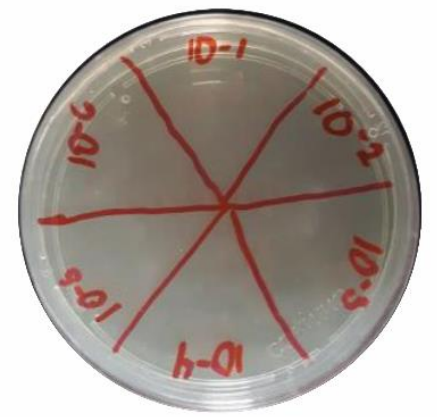

$20 \%$ PGL
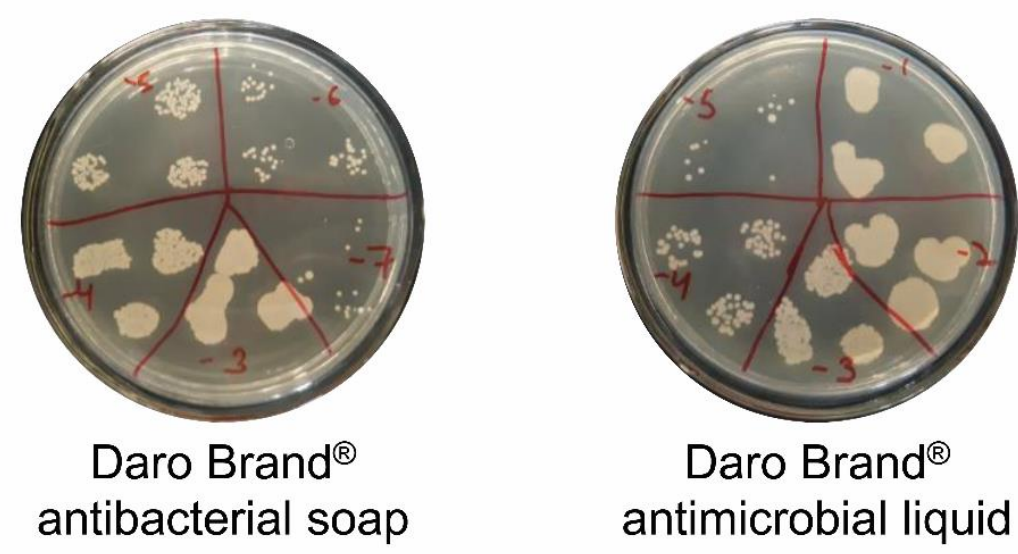

Source: Authors. 
Figure 4. Mean values and standard error of the number of adhered cells of Staphylococcus aureus per mL for each type of maxillofacial elastomer and disinfectant treatment. Different capital letters indicate a statistically significant difference between disinfectant treatments ( $p=0.020$; ANOVA).

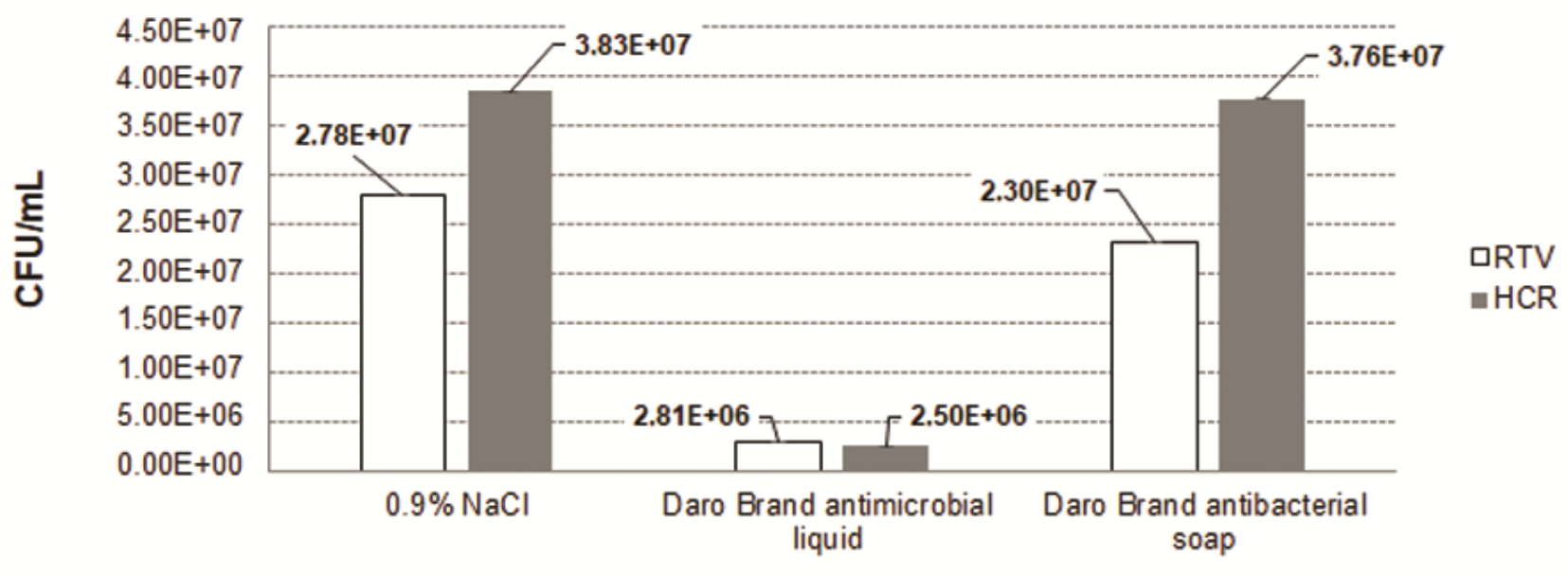

Desinfection treatments

Source: Authors.

Table 2. Result of two-way ANOVA for log colony forming units per millimeter.

\begin{tabular}{lccccc}
\hline Variation factors & df & $\begin{array}{c}\text { Sum of } \\
\text { squares }\end{array}$ & $\begin{array}{c}\text { Mean } \\
\text { square }\end{array}$ & F & p value \\
\hline Types of elastomers & 1 & 1.286 & 1.286 & 0.434 & 0.523 \\
Disinfectant treatment & 2 & 32.971 & 16.486 & 5.558 & $0.020^{*}$ \\
Type $v$ s. treatment & 2 & 2.713 & 1.356 & 0.457 & 0.644 \\
Error & 12 & 35.592 & 2.966 & & \\
Total & 17 & 72.563 & & & \\
\hline
\end{tabular}

${ }^{*} p<0.05$ denotes a statistically significant difference. Source: Authors.

Among the disinfectant treatments, there were lower numbers of CFU for specimens treated with the antimicrobial Daro Brand® (liquid) and the positive control with $0.9 \%$ saline solution of both maxillofacial elastomers, with a statistically significant difference ( $p=0.04$; Tukey's test) (Figure 4; Table 2), regardless of the type of maxillofacial elastomer used.

\section{Discussion}

Although there is evidence that propolis has been used since the time of Ancient Egypt, mainly to embalm bodies (Sforcin, 2016), recent studies have focused on the green propolis extract derived from Baccharis dracunculifolia (Azevedo et al, 2021; Miranda et al, 2019; Sforcin, 2016; Yamaga et al, 2021). This is due to its effectiveness in the treatment of oral conditions, including prosthetic stomatitis (Shui et al, 2021), and recently in the disinfection of complete dentures and maxillofacial prostheses (Capistrano et al, 2013; de Azevedo et al, 2021; de Souza et al, 2019; Miranda et al, 2019).

Considering that the prosthesis in contact with the skin provides a favorable environment for the reservoir of opportunistic microorganisms such as Candida spp. and S. aureus (Ariani et al, 2012), the latter, indeed, may cause atopic dermatitis in most individuals who wear maxillofacial prostheses (Cavalcante et al, 2021). Herein, a simulation of the 
conditions found on the contact interface between maxillofacial prostheses and facial defects was performed, with bacterial biofilm growth on maxillofacial elastomers. Based on this, among the disinfectants employed in the present study, Brazilian PGL solutions proved to be an effective and promising antibacterial disinfectant agent against the biofilm formed by S. aureus on the surface of maxillofacial silicone elastomers. Accordingly, previous studies have demonstrated that the antimicrobial effects of propolis are directly proportional to its concentration (Awale et al, 2005; de Azevedo et al, 2021). This fact is expected, since propolis has specific components (e.g., flavonoids, aromatic acids and esters), in addition to a bactericidal action due to cinnamic acid and coumarin (Sforcin, 2016; Yamaga et al, 2021). Propolis is more efficient against gram-positive bacteria such as $S$. aureus, used in this study. In fact, all PGL concentrations revealed a broad spectrum of antibiofilm action since there was no bacterial growth in the specimens treated with such solutions. This certainly supports the idea that propolis constituents act on membrane permeability, inhibiting bacterial motility (Sforcin, 2016).

The proven quality of action of the propolis substance, associated with ease of preparation and use, affordable cost, and the absence of adverse reactions, supports the use of natural products (phytotherapeutics) as relevant agents in maintaining the health of rehabilitated individuals (dos Santos et al, 2012). Disinfection with a propolis extract solution has the great advantage of not requiring mechanical cleaning, which is harmful to maxillofacial prostheses (Henriques et al, 2005). Furthermore, it is an easily accessible product, found in various parts of the world and with few regional variations in its formula (Sforcin, 2016). In this respect, the propolis extract obtained with an $11 \%$ glycolic solution showed effective results as a disinfectant of maxillofacial elastomers regarding long-term color change (Miranda et al, 2019). In addition, this formulation for the preparation of plant extracts yields more stable emulsified pharmaceutical forms since it provides information that guarantees the success of replacing $93.7 \%$ alcohol (w/w) as an extraction liquid in the preparation of propolis extracts (Kubiliene et al, 2015).

As expected in our study, the results of $2 \% \mathrm{CHX}$, a solution consolidated in the literature as an antimicrobial agent (Guiotti et al, 2016), were similar to those detected for PGL solutions. Nevertheless, a study has reported that CHX was less effective as an antimicrobial agent against a mixed-species biofilm, including S. epidermidis, S. xylosus, C. albicans, C. parapsilosis, and C. famata (Ariani et al, 2015). On the other hand, 2\% CHX was effective as a chemical disinfectant for maxillofacial prostheses without causing color alteration in pigmented and non-pigmented maxillofacial elastomers (Chamaria et al, 2019; Miranda et al, 2019). PGL solutions are expected to be effective in disinfecting silicone elastomers without color changes. Nonetheless, further studies are necessary to determine the effectiveness of disinfecting with PGL at different concentrations at the time of growth and in a mixed colony, as documented by Ariani et al. (2015).

Interestingly, we found that the Daro Brand ${ }^{\circledR}$ liquid antimicrobial solution was effective compared to control. As far as we know, no studies on the disinfection of maxillofacial prostheses with these products have been published. Also, some antibacterial soaps have produced clinically unacceptable color changes for silicone, so that they should be used with caution as disinfectants (Chamaria et al, 2019). Taken together, the present data show that the use of propolis extracts applied to a maxillofacial prosthesis can satisfy part of the great need for better hygiene and disinfection protocols, considerably facilitating the adaptation and prolonged use of these prostheses.

\section{Conclusion}

Within the limitations of this in vitro analysis, we demonstrated that the effects of PGL at different concentrations are similar to those of a $2 \% \mathrm{CHX}$ solution as a broad-spectrum S. aureus antibiofilm applied to a maxillofacial silicone elastomer by immersion for 15 minutes. In contrast, treatment with a specific antimicrobial (liquid) Daro Brand® revealed a lower number of CFU, compared to the distilled water control. Finally, also of paramount importance would be studies with the 
perspective that links quality of life to individual acceptance in relation to the continuous use of propolis-based solutions, since they have a characteristic smell that can be unpleasant.

\section{Acknowledgments}

We appreciate the financial support received from the Programa Institucional de Bolsas de Iniciação Cientifica (PIBIC) within the scope of the Conselho Nacional de Desenvolvimento Científico e Tecnológico, Brazil. We also thank Coordenação de Aperfeiçoamento de Pessoal de Nível Superior, Brazil (Finance code 001). J.A.A.A. is the recipient of a fellowship. Mrs. E. Greene provided English editing of the manuscript.

\section{References}

Ariani, N., Visser, A., Teulings, M. R., Dijk, M., Rahardjo, T. B., Vissink, A., \& van der Mei, H. C. (2015). Efficacy of cleansing agents in killing microorganisms in mixed species biofilms present on silicone facial prostheses--an in vitro study. Clinical Oral Investigations, 19(9), $2285-2293$.

Ariani, N., Vissink, A., van Oort, R. P., Kusdhany, L., Djais, A., Rahardjo, T. B., van der Mei, H. C., \& Krom, B. P. (2012). Microbial biofilms on facial prostheses. Biofouling, 28(6), 583-591.

Awale, S., Shrestha, S. P., Tezuka, Y., Ueda, J. Y., Matsushige, K., \& Kadota, S. (2005). Neoflavonoids and related constituents from Nepalese propolis and their nitric oxide production inhibitory activity. Journal of Natural Products, 68(6), 858-864.

Capistrano, H. M., de Assis, E. M., Leal, R. M., Alvarez-Leite, M. E., Brener, S., \& Bastos, E. M. (2013). Brazilian green propolis compared to miconazole gel in the treatment of Candida-associated denture stomatitis. Evidence-based Complementary and Alternative Medicine, $2013,947980$.

Cavalcante, F. S., Saintive, S., Carvalho Ferreira, D., Rocha Silva, A. B., Guimarães, L. C., Braga, B. S., Dios Abad, E., Ribeiro, M., \& Netto Dos Santos, K. R. (2021). Methicillin-resistant Staphylococcus aureus from infected skin lesions present several virulence genes and are associated with the CC30 in Brazilian children with atopic dermatitis. Virulence, 12(1), 260-269.

Chamaria, A., Aras, M. A., Chitre, V., \& Rajagopal, P. (2019). Effect of chemical disinfectants on the color stability of maxillofacial silicones: An in vitro study. Journal of Prosthodontics, 28(2), e869-e872.

Azevedo, M. N., Marques, N. T., Fonseca, M., Schuch, L. F., de Arruda, J., Santos, V. R., Mesquita, R. A., \& Moreno, A. (2021). Disinfectant effects of Brazilian green propolis alcohol solutions on the Staphylococcus aureus biofilm of maxillofacial prosthesis polymers. The Journal of Prosthetic Dentistry, S0022-3913(21)00193-1.

Caxias, F. P., Dos Santos, D. M., Bannwart, L. C., de Moraes Melo Neto, C. L., \& Goiato, M. C. (2019). Classification, history, and future prospects of maxillofacial prosthesis. International Journal of Dentistry, 2019, 8657619.

Souza, R. F., Silva-Lovato, C. H., de Arruda, C. N., Regis, R. R., Zanini, A. P., Longo, D. L., Peracini, A., de Andrade, I. M., Watanabe, E., \& Paranhos, H. F. (2019). Efficacy of a propolis solution for cleaning complete dentures. American Journal of Dentistry, 32(6), 306-310.

Santos, D. M., Goiato, M. C., Moreno, A., Pesqueira, A. A., Dekon, S. F. C., \& Guiotti, A. M. (2012). Effect of addition of pigments and opacifier on the hardness, absorption, solubility and surface degradation of facial silicone after artificial ageing. Polymer Degradation and Stability, 97(8):1249-1253.

Filié Haddad, M., Coelho Goiato, M., Micheline Dos Santos, D., Moreno, A., Filipe D'almeida, N., \& Alves Pesqueira, A. (2011). Color stability of maxillofacial silicone with nanoparticle pigment and opacifier submitted to disinfection and artificial aging. Journal of Biomedical Optics, 16(9), 095004.

Goiato, M. C., Pesqueira, A. A., Ramos da Silva, C., Gennari Filho, H., \& Micheline Dos Santos, D. (2009). Patient satisfaction with maxillofacial prosthesis. Literature review. Journal of Plastic, Reconstructive \& Aesthetic Surgery, 62(2), 175-180.

Goiato, M. C., Zucolotti, B. C., Mancuso, D. N., dos Santos, D. M., Pellizzer, E. P., \& Verri, F. R. (2010). Care and cleaning of maxillofacial prostheses. The Journal of Craniofacial Surgery, 21(4), 1270-1273.

Gonçalves, N. L., Borges, V. M., de Arruda, J., Dos Santos, E. G., Diniz, I., Madeira, M., \& Moreno, A. (2020). Antimicrobial effects of photodynamic therapy on Staphylococcus aureus biofilm grown on a specific acrylic resin surface for ocular prostheses. Photodiagnosis and Photodynamic Therapy, 32, 102042 .

Guiotti, A. M., Cunha, B. G., Paulini, M. B., Goiato, M. C., Dos Santos, D. M., Duque, C., Caiaffa, K. S., Brandini, D. A., Narciso de Oliveira, D. T., Brizzotti, N. S., \& Gottardo de Almeida, M. T. (2016). Antimicrobial activity of conventional and plant-extract disinfectant solutions on microbial biofilms on a maxillofacial polymer surface. The Journal of Prosthetic Dentistry, 116(1), 136-143.

Guiotti, A. M., da Silva, E., Catanoze, I. A., de Carvalho, K., Malavazi, E. M., Goiato, M. C., Dos Santos, D. M., \& de Almeida, M. (2018). Microbiological analysis of conjunctival secretion in anophthalmic cavity, contralateral eye and ocular prosthesis of patients with maxillofacial abnormalities. Letters in Applied Microbiology, 66(2), 104-109.

Hatamleh, M. M., Polyzois, G. L., Nuseir, A., Hatamleh, K., \& Alnazzawi, A. (2016). Mechanical properties and simulated aging of silicone maxillofacial elastomers: Advancements in the past 45 Years. Journal of Prosthodontics, 25(5), 418-426.

Henriques, M., Sousa, C., Lira, M., Elisabete, M., Oliveira, R., Oliveira, R., \& Azeredo, J. (2005). Adhesion of Pseudomonas aeruginosa and Staphylococcus epidermidis to silicone-hydrogel contact lenses. Optometry and Vision Science, 82(6), 446-450. 
Jablonski, R. Y., Veale, B. J., Coward, T. J., Keeling, A. J., Bojke, C., Pavitt, S. H., \& Nattress, B. R. (2021). Outcome measures in facial prosthesis research: A systematic review. The Journal of Prosthetic Dentistry, 126(6), 805-815.

Kubiliene, L., Laugaliene, V., Pavilonis, A., Maruska, A., Majiene, D., Barcauskaite, K., Kubilius, R., Kasparaviciene, G., \& Savickas, A. (2015). Alternative preparation of propolis extracts: comparison of their composition and biological activities. BMC Complementary and Alternative Medicine, 15, 156.

Li, X., Kolltveit, K. M., Tronstad, L., \& Olsen, I. (2000). Systemic diseases caused by oral infection. Clinical Microbiology Reviews, 13(4), 547-558.

Miranda, N. B., de Arruda, J., de Almeida, S., Dos Santos, E. G., Medeiros, I. S., \& Moreno, A. (2019). Optical parameters and hardness of two maxillofacial elastomers after immersion in different solutions of Brazilian green propolis extract. The Journal of Prosthetic Dentistry, 122(2), 168-175.

Moreno, A., Dos Santos, D. M., Lamartine de Moraes Melo Neto, C., Luiz de Melo Moreno, A., de Magalhães Bertoz, A. P., \& Goiato, M. C. (2020). In vitro evaluation of the effect of different disinfectants on the biofilm of Staphylococcus epidermidis and Staphylococcus aureus formed on acrylic ocular prostheses. PloS One, 15(10), e0240116.

Moreno, A., Goiato, M. C., dos Santos, D. M., Haddad, M. F., Pesqueira, A. A., \& Bannwart, L. C. (2013). Effect of different disinfectants on the microhardness and roughness of acrylic resins for ocular prosthesis. Gerodontology, 30(1), 32-39.

Mulcare, D. C., \& Coward, T. J. (2019). Suitability of a mobile phone colorimeter application for use as an objective aid when matching skin color during the fabrication of a maxillofacial prosthesis. Journal of Prosthodontics, 28(8), 934-943.

Paranhos, R. M., Batalhão, C. H., Semprini, M., Regalo, S. C., Ito, I. Y., \& de Mattos, M. (2007). Evaluation of ocular prosthesis biofilm and anophthalmic cavity contamination after use of three cleansing solutions. Journal of Applied Oral Science, 15(1), 33-38.

Pinheiro, J. B., Vomero, M. P., do Nascimento, C., Watanabe, E., Paranhos, H., Coto, N. P., Dias, R. B., Oliveira, V. C., \& Silva-Lovato, C. H. (2018). Genomic identification of microbial species adhering to maxillofacial prostheses and susceptibility to different hygiene protocols. Biofouling, $34(1)$, 15-25.

Rahman, A. M., Jamayet, N. B., Nizami, M., Johari, Y., Husein, A., \& Alam, M. K. (2019). Effect of aging and weathering on the physical properties of maxillofacial silicone elastomers: A systematic review and meta-analysis. Journal of Prosthodontics, 28(1), 36-48.

Sforcin J. M. (2016). Biological properties and therapeutic applications of propolis. Phytotherapy Research, 30(6), 894-905.

Shui, Y., Li, J., Lyu, X., \& Wang, Y. (2021). Phytotherapy in the management of denture stomatitis: A systematic review and meta-analysis of randomized controlled trials. Phytotherapy Research, 35(8), 4111-4126.

Sonnahalli, N. K., \& Chowdhary, R. (2020). Effect of nanoparticles on color stability and mechanical and biological properties of maxillofacial silicone elastomer: A systematic review. Journal of Indian Prosthodontic Society, 20(3), 244-254.

Tong, S. Y., Davis, J. S., Eichenberger, E., Holland, T. L., \& Fowler, V. G., Jr (2015). Staphylococcus aureus infections: epidemiology, pathophysiology, clinical manifestations, and management. Clinical Microbiology Reviews, 28(3), 603-661.

Yamaga, M., Tani, H., Nishikawa, M., Fukaya, K., Ikushiro, S. I., \& Murota, K. (2021). Pharmacokinetics and metabolism of cinnamic acid derivatives and flavonoids after oral administration of Brazilian green propolis in humans. Food \& Function, 12(6), 2520-2530. 